Jurnal Agroteknologi, Vol. 6 No. 1, Agustus $2015: 33$ - 40

\title{
INDUKSI KALUS PASAK BUMI (Eurycoma longifolia Jack) MELALUI EKSPLAN DAUN DAN PETIOL
}

(Callus Induction of Eurycoma longifolia Jack by Leaf and Petiole Explant)

ROSMAINA ${ }^{1}$, ZULFAHMI ${ }^{1}$, PROBO SUTEJO ${ }^{2}$, ULFIATUN² DAN MAISUPRATINA²

'Laboratorium Pemuliaan dan Genetika Fakultas Pertanian dan Peternakan

${ }^{2}$ Alumni Program Studi Agroteknologi Fakultas Pertanian dan Peternakan

UIN Sultan Syarif Kasim Riau Kampus Raja Ali Haji Jl. H.R. Soebrantas Km 15 Pekanbaru

E-mail: rosmaina@uin-suska.ac.id

\begin{abstract}
One of the problem of Eurycoma longifolia Jack propagation was low germination percentage due to recalcitrant seeds and slow growth of seedling from cutting propagation. To overcome this problem is required propagation of Eurycoma longifolia via in vitro culture. The objective of this research was to know the effect of Auxin (2,4-D and NAA) and Cytokines (BAP and Kinetin) on Eurycoma longifolia callus induction via leaf and petiole explants. In this study, we used plant growth regulator of 2,4 D, NAA, $B A P$ and Kinetin in several levels. The observed variables were appearing callus time, callus color and callus texture. The results of this study showed that MS medium supplemented with $1 \mathrm{ppm} \mathrm{NAA+1 \textrm {ppm }}$ $B A P$ was able to induce callus formation in leaf explant for 6 months after culture. While MS medium supplemented with 1 ppm 2,4-D, 1 ppm BAP, combination of 2,4-D and Kinetin and combination of 2,4$D$ and $B A P$ can induce callus formation from petiole. All the callus formation has yellow color and yellow brown color. The petiole explant that is grown in MS medium supplemented with 1 ppm BAP induced of callus in short time (18 days after culture).
\end{abstract}

Keywords: Eurycoma longifolia, BAP, 2,4-D,NAA, Kinetin, callus induction.

\section{PENDAHULUAN}

Indonesia memiliki kekayaan berbagai jenis tanaman yang berkhasiat sebagai obat, seperti pasak bumi (Eurycoma longifolia Jack). Spesies ini termasuk dalam anggota famili Simaroubaceae, tanaman pasak bumi hanya ditemui di wilayah Semenanjung Malaysia, Sumatera dan Kalimantan. Di pulau Sumatera pasak bumi tumbuh dikawasan Taman Nasional Gunung Leuser, Riau (Rosmaina \& Zulfahmi, 2013) dan Taman Nasional Kerinci Seblat, Bengkulu (Heriyanto et al., 2006). Tanaman pasak bumi termasuk salah satu tanaman yang dilindungi berdasarkan Keputusan Menteri Pertanian Nomor: 511/Kpts/PD.310/9/2006.

Pasak bumi (Eurycoma Longifolia Jack) merupakan salah satu tanaman obat yang belum banyak dikembangkan, padahal tanaman ini memiliki banyak khasiat, seperti ekstrak akar Eurycoma longifolia Jack dapat meredakan nyeri pada lambung (Kosala, 2010), sumber insektisida nabati (Lina et al., 2005), memperbaiki nafsu makan, disentri, demam, lemah dan febrifugum (Utami, 2008), menghambat sel kanker payudara, leukemia atau kanker darah (Tee \& Azimahtol, 2005) dan kanker paru- paru (Untung, 2007), mencegah osteoporosis (Effendy et al., 2012), dapat mengobati HIV (Sindelar et al., 2005), anti malaria (Bhat and Kasim, 2010; Chan et al., 2005) dan berfungsi sebagai afrodisiak atau obat kuat (Nainggolan dan Simanjuntak, 2005). Industri obat-obatan selama ini hanya mengandalkan tanaman pasak bumi dari alam tanpa adanya upaya budidaya, akibatnya terjadi penurunan populasi pasak bumi di alam melalui pemanenan akar yang berlebih-lebihan (Susilowati et al., 2008). Perbanyakan pasak bumi dengan menggunakan biji sulit dilakukan karena benihnya bersifat rekalsitran (Sanmugam et al, 2014), persentase perkecambahan secara alaminya sangat rendah serta membutuhkan waktu yang cukup lama, hal ini disebabkan karena embrio yang belum cukup masak pada saat pemencaran (Hussein et al., 2005). Perbanyakan pasak bumi secara vegetatif masih sulit dan membutuhkan waktu lama. Solfan et al. (2010) melaporkan perbanyakan pasak bumi melalui stek batang menunjukkan persentase tumbuh yang rendah yaitu hanya $45 \%$ dari seluruh perlakuan selama 6 bulan. Perbanyakan 
melalui stek pucuk yang dilaporkan oleh Susilowati et al. (2008) membutuhkan waktu selama 6 bulan dan berhasil mendapatkan $78 \%$ bahan tanam dapat tumbuh.

Teknik kultur jaringan merupakan salah satu teknologi perbanyakan secara vegetatif, teknik ini memiliki keuntungan yaitu dapat melalukan perbanyakan secara massa dalam waktu yang relatif cepat terutama untuk tanaman yang sulit diperbanyak secara vegetative dan generatif, tidak merusak pohon induk karena membutuhkan sedikit ekplan, dapat memproduksi metabolit sekunder melalui kultur kalus, dan menghasilkan bibit yang sehat. Teknik kultur jaringan ini dapat dijadikan sebagai alternatif pemecahan masalah bagi perbanyakan bibit dan untuk memperoleh produksi metabolit sekunder dari tanaman pasak bumi, beberapa penelitian yang telah menggunakan teknik kultur jaringan pada tanaman pasak bumi dilaporkan oleh Sitorus et al., (2011); Siregar, (2010); Siregar et al., (2006); Hussain et al, (2005); Hussein et al., (2006); Keng et al, (2010); Mahmood et al, (2011); Balakrishnan et al, (2012); Hassan et al, (2012); Hussein et al., (2012); Parikrama, and Esyanti, (2014); Irawati et al, (2014). Beberapa senyawa metabolit sekunder pada pasak bumi diantaranya ialah alkaloids, terpenoid, sterpenoid, steroid, flavonoid (fenol) dan saponin (Ayob et al, 2013; Irawati et al, 2014; Rahmawati, 2014; Parikrama\&Esyanti, 2014; Normakiah\&Laela, 2010; Nurhanan et al, 2005 dan Ang et al, 1999).

Kombinasi zat pengatur tumbuh ke dalam media merupakan salah satu faktor yang menentukan keberhasilan kultur in vitro. Zat pengatur tumbuh (ZPT) yang sering digunakan untuk menginduksi pembentukan kalus adalah auksin dan sitokinin. Diantara golongan auksin yang umum digunakan pada media kultur jaringan pasak bumi adalah 2,4-D (Dichlorophenoxyacetic acid) dan NAA, sedangkan jenis sitokinin yang banyak digunakan untuk kultur pasak bumi adalah kinetin dan BAP (Sitorus et al., 2011; Siregar, 2010; Siregar et al., 2005; Hussain et al, 2005; Hussein et al., 2006; Keng et al, 2010; Mahmood et al, 2011; Balakrishnan et al, 2012; Balakrishnan et al, 2014; Hassan et al, 2012; Hussein et al., 2012; Parikrama, and Esyanti, 2014 dan Irawati et al, 2014). 2,4-D memiliki sifat lebih stabil karena tidak mudah terurai oleh enzim-enzim yang dikeluarkan oleh sel tanaman ataupun oleh pemanasan pada proses sterilisasi, selain itu golongan auksin berfungsi untuk merangsang pertumbuhan kalus, suspensi sel dan organ (Gunawan, 1988). Pemberian sitokinin dalam kultur kalus berperan penting dalam memicu pembelahan dan pemanjangan sel (Indah dan Ermavitalini, 2013). Penelitian ini bertujuan untuk melihat pengaruh pemberian auksin (2,4-D dan NAA) dan Stokinin (Kinetin dan BAP) terhadap induksi kalus pasak bumi.

\section{BAHAN DAN METODE}

Penelitian ini dilaksanakan pada bulan Oktober 2013 sampai Mei 2014 di Laboratorium Pemulian dan Genetik Fakultas Pertanian dan Peternakan Universitas Islam Negeri Sultan Syarif Kasim Riau. Bahan yang digunakan adalah daun muda dan petiol daun pasak bumi, Media MS, Zat Pengatur Tumbuh Auksin (2,4D, dan NAA) dan Sitokinin (BAP dan Kinetin), agar, gula, fungisida (Benlate) dan bakterisida (Streptomycin). Alat yang digunakan Seperangkat alat tanaman kultur Jaringan $\mathrm{pH}$ meter, laminar air flow cabinet.

Penelitian ini terdiri dari 3 percobaan dengan tujuan mengoptimasi komposisi zat pengatur tumbuh yang dapat menginduksi munculnya kalus dan tunas pada tanaman pasak bumi. Adapun rancangan yang digunakan yaitu:

1. Percobaan ke-1 menggunakan rancangan Acak lengkap factorial, dimana factor pertama adalah auksin (NAA) dengan konsentrasi 0 ppm NAA, 1 ppm NAA dan 2 ppm NAA. Sedangkan factor kedua adalah Sitokinin (BAP) dengan konsentrasi 0 ppm BAP, 1 ppm BAP dan 2 ppm BAP sehingga pada penelitian pertama terdapat 9 perlakuan dengan masing-masing 10 ulangan.

2. Percobaan ke-2 menggunakan Rancangan acak lengkap factorial, dimana factor pertama berbagai taraf konsentrasi 2,4-D yaitu $0,1,3$ dan $4 \mathrm{ppm}$ dan faktor kedua adalah konsentrasi Kinetin yaitu 0 ppm, 1 ppm dan 2 ppm kinetin, sehingga terdapat 12 kombinasi percobaan dengan masingmasing 10 ulangan.

3. Percobaan ke-3 menggunakan Rancangan acak lengkap factorial, dimana factor pertama berbagai taraf konsentrasi 2,4-D yaitu $0 \mathrm{ppm}, 0.5 \mathrm{ppm}, 0.75 \mathrm{ppm}$, dan $1 \mathrm{ppm}$ dan factor kedua adalah konsentrasi BAP yaitu $0 \mathrm{ppm}, 1 \mathrm{ppm}$ dan 1,5 ppm BAP, sehingga terdapat 12 kombinasi percobaan dengan masing-masing 10 ulangan 


\section{Sterilisasi eksplan}

Teknik sterilisasi eksplan daun dan petiol dilakukan dengan cara: eksplan daun dan petiol dicuci menggunakan air mengalir dan sunlight sampai bersih, selanjutnya dibilas dengan air steril. Setelah pencucian, dilakukan perendaman dalam fungisida Benlate $(2 \mathrm{~g} / 100$ $\mathrm{ml})$ selama 60 menit lalu dibilas dengan air steril, dilanjutkan perendam dalam fungisida Streptomysin ( $2 \mathrm{~g} / 100 \mathrm{ml}$ ) selama 60 menit, lalu dibilas dengan air steril. Setelah itu eksplan dibawa ke dalam laminar, dan direndam kembali dalam larutan klorox $10 \%$ selama 10 menit, bilas dengan air steril, lalu masukkan dalam larutan klorox $5 \%$ selama 5 menit, bilas dengan air steril dan rendam dalam alkohol $70 \%$ selama 5 menit, lalu dibilas dengan air steril sebanyak 3x. Eksplan yang sudah disterilkan ditanam dalam media MSO selama 7 hari untuk mendapatkan eksplan yang steril. Kemudian eksplan daun yang berhasil survive diambil kembali kemudian dipotong-potong dengan ukuran $(0,7 \mathrm{~cm} \times 0,7 \mathrm{~cm})$ sedangkan eksplan petiol dengan ukuran $(0,5 \mathrm{~cm})$, selanjutnya dilakukan penanaman pada media perlakuan. Pengamatan dilakukan terhadap waktu muncul kalus, warna kalus dan tekstur kalus. Data disajikan secara deskriptif.

\section{HASIL DAN PEMBAHASAN}

Rekapitulasi hasil tiga percobaan terhadap induksi kalus paak bumi (Eurycoma longifolia Jack dapat dilihat pada Tabel 1. Dari tiga percobaan yang dilakukan, masing-masing menunjukkan hasil yang berbeda. Tetapi tidak ada kalus yang mampu terbentuk pada media tanpa tambahan zat pengatur tumbuh. Hal serupa juga dilaporkan oleh Hussein et al, (2005) dan Vijendren et al, (2010). Dari percobaan pertama yang mengkombinasikan berbagai taraf NAA dan BAP hanya satu perlakuan yang berhasil membentuk kalus yaitu 1 ppm NAA+ 1 ppm kan BAP dengan persentase pembentukan kalus sebesar $20 \%$. Waktu munculnya kalus sangat lama yaitu sekitar 6 bulan setelah kultur dan eksplan yang digunakan berupa daun,sedangkan perlakuan lainnya tidak berhasil memberhasil membentuk kalus. Kalus yang terbentuk dari perlakuan ini sangat padat, kompak dan berwarna putih kekuningan (Gambar 1). Hasil ini lebih rendah dari yang dilaporkan oleh Hussain pada eksplan daun yang mampu menginduksi kalus sebesar $50-90 \%$ kalus dengan waktu induksi hanya sekita 2-4 MST. Dan Perbedaan ini diduga karena sumber eksplan yang digunakan berasal dari perkecambahan steril secara in vitro, sehingga jaringan daun yang digunakan masih sangat meristematik. Sedangkan pada penelitian ini ekplana yang digunakan berasal dari hutan dan daun yang digunakan sudah agak tua. Hasil lain yang berbeda dilaporkan oleh Hassan et al, (2012) bahwa penggunaan BAP mampu menginduksi munculnya tunas tidak hanya kalus.

Tabel 1. Rekapitulasi hasil tiga percobaan terhadap induksi kalus paak bumi (Eurycoma longifolia Jack

\begin{tabular}{|c|c|c|c|c|}
\hline No & Perlakuan & Eksplan & $\begin{array}{c}\text { Waktu } \\
\text { Muncul Kalus }\end{array}$ & Bentuk dan Warna Kalus \\
\hline \multicolumn{5}{|c|}{ Percobaan I } \\
\hline 1 & 1 ppm NAA + 2 ppm BAP & Daun & 6 Bulan & $\begin{array}{l}\text { Kalus padat dan kompak, berwarna putih } \\
\text { kekuningan }\end{array}$ \\
\hline \multicolumn{5}{|c|}{ Percobaan II } \\
\hline 1 & 1 ppm 2,4-D+ 2 ppm Kinetin & petiol & $26 \mathrm{HST}$, & Padat, kopak dan berwarna coklat muda \\
\hline 2 & 3 ppm 2,4-D+ 1 ppm Kinetin & petiol & 35 HST & Padat, kopak dan berwarna coklat muda \\
\hline 3 & 4 ppm 2,4- D + 1 ppm Kinetin & petiol & $44 \mathrm{HST}$ & Padat, kopak dan berwarna coklat gelap \\
\hline 4 & 1 ppm Kinetin & petiol & 42 HST & Padat, kopak dan berwarna coklat muda \\
\hline \multicolumn{5}{|c|}{ Percobaan III } \\
\hline 1 & 1 ppm 2,4-D & petiol & $37 \mathrm{HST}$ & $\begin{array}{l}\text { Padat dan kompak, berwarna kuning } \\
\text { hingga coklat muda }\end{array}$ \\
\hline 2 & 1 ppm BAP & petiol & $18 \mathrm{HST}$ & $\begin{array}{l}\text { Padat dan kompak, berwarna kuning } \\
\text { hingga coklat muda }\end{array}$ \\
\hline 3 & 1.5 ppm BAP & petiol & 49 HST & $\begin{array}{l}\text { Padat dan kompak, berwarna kuning } \\
\text { hingga coklat muda }\end{array}$ \\
\hline 4 & 1 ppm BAP + 1 ppm 2,4-D & petiol & $49 \mathrm{HST}$ & $\begin{array}{l}\text { Padat dan kompak, berwarna kuning } \\
\text { hingga coklat muda }\end{array}$ \\
\hline 5 & 1.5 ppm BAP+ 1 ppm 2,4-D & petiol & $23 \mathrm{HST}$ & $\begin{array}{l}\text { Padat dan kompak, berwarna kuning } \\
\text { hingga coklat muda }\end{array}$ \\
\hline
\end{tabular}


Dari percobaan yang kedua yang mengkombinasikan sitokinin (Kinetin) dan Auksin (2,4-D) dengan 12 kombinasi perlakuan hanya 4 perlakuan yang berhasil membentuk kalus yaitu 1 ppm 2,4-D+ 2 ppm Kinetin, 3 ppm 2,4-D+ 1 ppm Kinetin, 4 ppm 2,4- D + 1 ppm Kinetin dan $1 \mathrm{ppm}$ Kinetin. Percobaan kedua menggunakan 2 sumber eksplan yaitu petiol dan daun, tetapi hanya eksplan petiol yang berhasil menginduksi munculnya kalus, sedangkan eksplan daun tidak. Waktu munculnya kalus lebih cepat dibandingkan percobaan pertama yaitu 26-44 HST (hari setelah tanam). Perlakuan 1 ppm 2,4-D+2 ppm Kinetin mampu menginduksi munculnya kalus lebih cepat dibandingkan perlakuan lainnya pada percobaan kedua, sedangkan perlakuan 4 ppm 2,4- D + 1 ppm Kinetin menginduksi munculnya kalus lebih lama yaitu $44 \mathrm{HST}$. Semua kalus yang terbentuk pada percobaan ini memiliki struktur yang kompak, padat dan berwarna coklat muda kecuali pada perlakuan 4 ppm 2,4-D + 1 ppm Kinetin menghasilkan kalus yang kompak, padat dan berwarna coklat gelap (Gambar 1). Pembelahan sel yang mengarah pada terbentuknya kalus terjadi dari adanya respon terhadap luka dan suplai hormon baik secara eksogen maupun secara endogen dari eksplan. Munculnya kalus tidak hanya dipengaruhi oleh pelukaan dan penambahan zat pengatur tumbuh saja, tetapi juga konsentrasi sukrosa, jenis media yang digunakan dan sumber eksplan.
Dari percobaan ketiga yang mengkombinasikan Auksin (2,4-D) dan sitokinin (BAP) terdapat lima perlakuan yang mampu menginduksi munculnya kalus yaitu 1 ppm 2,4D, 1 ppm BAP, 1.5 ppm BAP, 1 ppm BAP + 1 ppm 2,4-D dan $1.5 \mathrm{ppm}$ BAP + $1 \mathrm{ppm}$ berasal 2,4-D. sedangkan percobaan yang menggunakan 2,4-D dibawah 1 ppm tidak mampu menginduksi munculnya kalus, artinya dari percobaan ketiga kalus baru bisa terbentuk ketika 2,4-D yang digunakan minimal $1 \mathrm{ppm}$. Berbeda dengan hasil yang dilaporkan oleh Hussein et al, (2005) bahwa 0.5 ppm 2.4-D mampu menginduksi munculnya kalus pada beberapa sumber eksplan yang digunakan. Eksplan yang digunakan berasal dari daun dan petiol tetapi yang berhasil menginduksi munculnya kalus hanya eksplan yang berasal dari petiol. Waktu munculnya kalus bervariasi antar perlakuan, tetapi percobaan ketiga ini menghasilkan kalus lebih cepat yaitu 18 HST pada perlakuan $1 \mathrm{ppm}$ BAP, diikuti oleh perlakuan $1.5 \mathrm{ppm} \quad \mathrm{BAP}+1 \mathrm{ppm} 2,4-\mathrm{D}$ yang berhasil menginduksi kalus pada hari ke 23 setelah tanam (Tabel 1). Sedangkan perlakuan $1.5 \mathrm{ppm}$ BAP dan perlakuan $1 \mathrm{ppm} \mathrm{BAP}+1$ ppm 2,4-D menginduksi waktu munculnya kalus sekitar 7 MST atau sekitar 49 HST. Kalus yang terbentuk pada percobaan yang ketiga memiliki tekstur yang kompak, padat dan berwarna kuning hingga coklat muda.

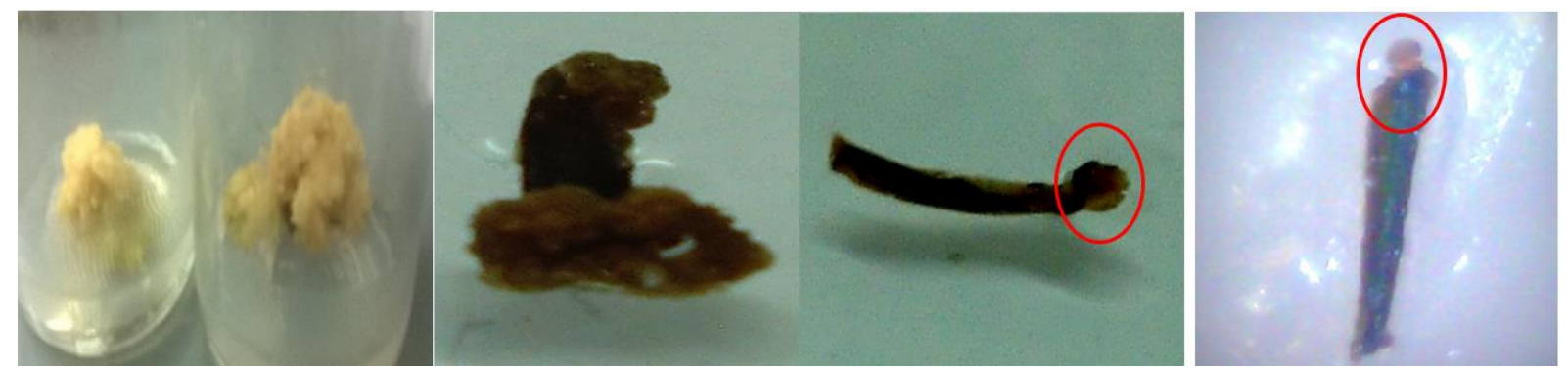

Gambar 1. Kalus Eurycoma longifolia Jack yang terbentuk [A] Kalus yang terbentuk dari perlakuan 1 ppm NAA + 2 ppm BAP eksplan daun (Percobaan pertama), [B] Kalus yang terbentuk pada pada petiol dari perlakuan 2,4-D $1 \mathrm{ppm}+$ Kinetin $2 \mathrm{ppm}$, [C] kalus yang terbentuk dari perlakuan 2,4 D 1 ppm eksplan petiol, [D] BAP 1 ppm sumber eksplan petiol.

Total persentase eksplan petiol yang mampu menumbuhkan kalus pada penelitian ini rata-rata sebesar 20\% (dari percobaan pertama, kedua dan ketiga).Persentase tumbuh sebesar 20\% merupakan persentase angka keberhasilan eksplan yang cukup besar. Mengingat eksplan yang digunakan berasal dari lapangan. Beberapa laporan menyebutkan keberhasilan induksi kalus pada tanaman berkayu yang menggunakan eksplan dari lapangan memiliki tingkat keberhasilannya yang rendah, seperti induksi kalus pada tanaman kayu ulin dengan persentase eksplan membentuk kalus sebesar 2,5\% (Hidayat, 2007). Kemudian pada eksplan kotiledon ujung tanaman jarak pagar dapat membentuk kalus dengan persentase $6.48 \%$ (Zulkarnain \& Lizawati, 2011). Berbeda dengan hasil yang 
dilaporkan oleh Mahmood (2010) berhasil menginduksi kalus pada eksplan daun sebesar $81,67 \%$ dan pada eksplan petiol sebesar $78,33 \%$, dimana eksplan yang digunakan merupakan planlet hasil perkecambahan biji secara in vitro. Pada setiap perlakuan zat pengatur tumbuh yang ditambahkan dalam media dengan konsentrasi berbeda menunjukkan perbedaan waktu muncul kalus yang berbeda pada masing-masing perlakuan.

Dari beberapa perlakuan yang dicobakan terdapat beberapa perlakuan auksin tunggal dan sitokinin tunggal yang mampu menginduksi munculnya kalus pada eksplan petiol yaitu perlakuan $1 \mathrm{ppm}$ Kinetin, $1 \mathrm{ppm}$ BAP, 1.5 ppm BAP dan 1 ppm 2,4-D. hal yang sama juga pernah dilaporkan oleh oleh Mahmood (2010) dan Mahmood et al, (2011); pada tanaman Eurycoma longifolia Jack induksi kalus dari petiol menggunakan 2,4-D tunggal berhasil menginduksi rata-rata mencapai $81,67 \%$, Hussein et al, (2005) menginduksi kalus menggunakan media MS+1 ppm 2,4-D dari eksplan kotiledon, Hassan et al, (2012) berhasil menginduksi kalus pasak bumi dengan penggunaan Auksin tunggal dengan berbagai dosis konsentrasi (NAA, IBA dan IAA), Khairunisa (2009) yang berhasil menginduksi kalus binahong paling banyak dengan menggunakan BAP tunggal pada konsentrasi 1 ppm. Hasil ini juga diperkuat oleh pernyataan Indah \& Ermavitalini (2013) bahwa penambahan auksin pada konsentrasi rendah akan memacu pembentukan kalus. Selain media dan konsentrasi zat pengatur tumbuh yang tepat Rahayu, (2003) melaporkan salah satu faktor keberhasilan pembentukan kalus adalah ada atau tidaknya kambium pada eksplan, apabila eksplan memiliki kambium akan mudah menginduksi kalus, diduga karena faktor inilah mengapa kalus pada petiol leih cepat terbentuk dibandingkan kalus pada eksplan daun (6 bulan) pada percobaan pertama dan pada percobaan ke-2 dan ke-3 eksplan daum belum membentuk kalus hingga $8 \mathrm{MST}$. Hal ini juga dikuatkan oleh pernyataan Gunawan (1988) bahwa bagian tanaman seperti embrio muda, hipokotil dan batang muda merupakan bagian yang mudah untuk berdiferensiasi dan menghasilkan kalus.

Indikator pertumbuhan eksplan secara

in vitro dapat dilihat dari warna dan stuktur kalus yang menggambarkan penampilan visual sehingga, dapat diketahui apakah suatu kalus masih memiliki sel-sel yang aktif membelah atau telah mati. Jaringan kalus yang dihasilkan dari suatu eksplan biasanya memunculkan warna yang berbeda-beda.Kualitas kalus yang baik memiliki warna yang hijau dan remah (friable) (Andaryani, 2010). Tekstur kalus yang remah dianggap baik karena memudahkan dalam pemisahan menjadi sel-sel tunggal pada kultur suspensi, di samping itu akan meningkatkan aerasi oksigen antar sel. Dari semua kalus yang terbentuk tidak diperoleh kalus yang berwarna hijau dan remah. Pada percobaan pertama diperoleh kalus kalus berwarna putih kekuningan dan sangat kompak (Gambar 1A) sedangkan dari percobaan ke-2 dan ke-3 warna yang terbentuk berwarna kuning hingga kecoklatan serta memiliki stuktur yang kompak dan padat. Peristiwa munculnya kalus berwarna kuning pada tanaman pasak bumi juga dilaporkan oleh Mahmood et al. (2010); Vijendren et al, 2010 dan Siregar et al. (2006), pada tanaman Alfalfa (Medicago sativa L.) (Hayati et al., 2010), dan kalus embriogenik jantung pisang curup (Marlin et al., 2012). warna kuning pada kalus diduga merupakan pigmen antosantin, pigmen antosantin ini adalah senyawa fenol dari kelompok flavonoid (Pierik, 1987 dalam Hayati et al., 2010). Senyawa fenol yang terbentuk pada kalus dalam penelitian ini merupakan bentuk respon eksplan terhadap luka karena pengirisan, sehingga akan memacu eksplan untuk melakukan usaha pertahanan diri. Usaha tersebut dilakukan dengan meningkatkan aktifitas metabolik sehingga dihasilkan senyawa metabolit sekunder yaitu fenol.Jika fenol yang terbentuk mengalami oksidasi maka dapat menyebabkan warna coklat pada kalus. Kalus yang memiliki tekstur kompak umumnya memiliki ukuran sel kecil dengan sitoplasma padat, inti besar dan memiliki banyak pati (karbohidrat) Dodd (1993) dalam Ariati et al., (2012). Zulkarnain \& Lizawati (2011) menambahkan kalus yang kompak ini dimungkinkan karena penggunaan komposisi media dan konsentrasi zat pengatur tumbuh dan asam amino yang kurang tepat. Dari semua perlakuan tidak ditemukan kalus embriogenik, Hussein et al, 2005 melaporkan kalus embriogenik hanya terbentuk dari eksplan kotiledon sedangkan eksplan daun, petiol, pucuk dan ujung akar hanya menghasilkan kalus yang kompak dan berwarna putih kekuningan. Embrio somatic yang telah matang dicirikan dengan warna embrio hijau terang dan memiliki bentuk globular. Iriawati et al, 2014 melaporkan kandungan metabolit sekunder pada tanaman pasak bumi paling tinggi ketika 
berada dalam bentuk kalus non-embriogenik yaitu sebesar $1.598 \%$ dibandingkan pada tahap embriogenik hanya $0.06 \%$ sehingga produksi kalus bias menjadi alternatif untuk peoduksi metabolite sekunder pada tanaman pasak bumi.

\section{KESIMPULAN DAN SARAN}

\section{Kesimpulan}

Dari penelitian ini Petiol atau tangkai daun dapat digunakan sebagai sumber ekplan pada kultur pasak bumi karena mampu lebih cepat menginduksi munculnya kalus. 2,4-D dan BAP tunggal dapat menginduksi kalus pasak bumi dalam waktu yang relative cepat.

\section{DAFTAR PUSTAKA}

Andaryani, S. 2010. Kajian Penggunaan Berbagai Konsentrasi BAP dan 2,4-D Terhadap Induksi Kalus Jarak Pagar (Jatrophacurcas L.) secara In Vitro. Skripsi, Universitas Sebelas Maret, Surakarta.

Ang, HH \& Cheang, HS. 1999. Studies on the Anxiolytic Activity of Eurycoma longifolia Jack Roots in Mice. Journal of Pharmacology. 79: 497-500.

Anggraeni, TDA., Emy S, \& Rully DP. 2012. Pengaruh Komposisi Media dan Sumber Eksplan Terhadap Induksi Kalus, Perkecambahan, dan Pertumbuhan Tunas Embrio Somatik Jarak Pagar. Buletin Tanaman Tembakau, Serat \& Minyak Industri. 4: 76-84.

Ayob Z, A Wagiran and AA Samad. 2013. Potential of Tissue Cultured Medicinal Plants in Malaysia. Jurnal Teknologi (Sciences \& Engineering) 62(1):111-117

Balakrishnan B, AL Julkifle, SS Rabiah, S Alwee,CL Keng, S Subramaniam. 2012. The effect of strain virulence on Agrobacterium rhizogenes transformation efficiency in Eurycoma longifolia. Proceedings of The 2nd Annual International Conference Syiah Kuala University 2012 \& The 8th IMT-GT Uninet Biosciences Conference Banda Aceh, 22-24 November 2012. P. 431-433

Balakrishnan B, SSRSD Alwee, CL Keng, and $S$ Subramaniam. 2014. Histology Of Somatic Embryos Of Eurycoma Longifolia (Simaroubaceae): Relevance In Agrobacterium Rhizogenes-Mediated
Transformation. Pak. J. Bot. 46(3): 10611064

Bhat $R$ and AA Kasim. 2010. Tongkat Ali (Eurycoma longifolia Jack): A Review on Its Ethnobotany and Pharmacological Importance. Fitoterapia. 81: 669-679.

Chan KL, CY Choo, NR Abdullah, \& Z Izmail. 2004. Anthiplasmodial Studies of Eurycoma longifolia Jack Using the Lacture Dehidrogenase Assy of Plasmodium Falciparum. Journal of Pharmacology. 92: 223-227.

Effendy NM, N Mohamed N, N Muhammad, IN Mohamad and AN Shuid. 2012. Eurycoma longifolia Medicinal Plant in the Prevention and Treatment of Male Osteoporosis due to Androgen Deficiency. Evidence-Based Complementary and Alternative Medicine. 9: 5362.

Gunawan LW. 1988. Teknik Kultur Jaringan Tumbuhan. Direktorat Jenderal Pendidikan Tinggi Departemen Pendidikan dan Kebudayaan. Institut Pertanian Bogor. Hal 152.

Handayani W, Y Nurcahayati and N Setiari. 2012. Respon Pertumbuhan dan Produksi Alkaloid pada Kalus Berakar Datura metel L. Terhadap Peningkatan Mikronutrien dari Medium MS. Buletin Anatomi dan Fisiologi, 20: 29-36.

Hassan NH, R Abdullah, LS Kiong, AR Ahmad, $\mathrm{N}$ Abdullah, $\mathrm{F}$ Zainudin, $\mathrm{H}$ Ismail and SSA Rahman. 2012. Micropropagation and production of eurycomanone, 9methoxycanthin-6-one and canthin-6one in roots of Eurycoma longifolia plantlets. African Journal of Biotechnology .11(26): 6818-6825

Heriyanto NM, S Reny and S Endro. 2006. Kajian Ekologi dan Potensi Pasak Bumi (Eurycoma longifolia Jack.) di Kelompok Hutan Sungai Manna-Sungai Nasal, Bengkulu. Buletin Plasma Nutfah. 12: 6975.

Hidayat R, A Sukarti, R Poerwanto, LK Darusman, BS Purwoko. 2005. Kajian Periode Dormansi dan Ritme Pertumbuhan Tunas dan Akar Tanaman Manggis (Garcinia mangostana L.). Buletin Agronomi, 33:16-22.

Hussein S, I Rusli, LPK Anna, NM Fadzillah, SK Daud. 2005. Micropropagation of Eurycoma Longifolia Jack Via Formatoin of Somatic Embryogenesis. Asian Journal of Plant Science. 4:472-485 
Hussein S, I Rusli and APK Ling. 2006. Adventitious Shoots Regeneration From Root and Stem Explants or Eurycoma longifolia Jack An Important Tropical Medicinal Plants. International Journal of Agricultural Research. 1: 183-193.

Hussein S, I Rusli, L Anna, MF Nor'aini and KD Siti. 2005. Multiple Shoots Formation of an Important Tropical Medicinal Plant, Eurycoma longifolia Jack. Plant Biotechnology. 22: 349-351.

Indah PN and D Ermavitalini. 2013. Induksi Kalus Daun Nyamplung (Calophyllum inophyllum Linn.) pada Beberapa Kombinasi Konsentrasi 6-Benzylaminopurine (BAP) dan 2,4-Dichlorophenoxyacetic Acid (2,4-D). Jurnal Sains dan Seni Pomits. 2: 1-6.

Iriawati, A Rahmawati, RR Esyanti. 2014. Analysis of Secondary Metabolite Productionin Somatic Embryo of Pasak Bumi (Eurycoma longifolia Jack.). Procedia Chemistry. 13:112 - 118

Keng CL, AS Wei, and A Bhatt. 2010. Elicitation effect on cell biomass and production of Alkaloids in cell suspension culture of the tropical tree Eurycoma longifolia. Research Journal of the Costa Rican Distance Education University.2(2): 239244

Kosala K. 2010. Uji Efek Proteksi Akar Pasak Bumi (Eurycoma longifolia Jack) Terhadap Ulkus Lambung Tikus yang Diinduksi dengan Ligasi Pilori. Jurnal Media Sains. 2: 2085-3548.

Mahmood M, R Normi and S Subramaniam. 2010. Optimization of suitable auxin application in a recalcitrant woody forest plant of Eurycoma longifolia (Tongkat Ali) for callus induction. African Journal of Biotechnology, 9 (49): 8417-8428.

Mahmood M, R Normi and S Subramaniam. 2011. Distribution of 9-methoxycanthin6 -one from the intact plant parts and callus cultures of Eurycoma longifolia (Tongkat Ali). Australian Journal Crop Science. 5(12):1565-1569

Nainggolan $O$ and JW Simanjuntak. 2005. Pengaruh Ekstrak Ethanol Akar Pasak Bumi Terhadap Perilaku Seksual Mencit Putih. Cermin Dunia Kedokteran. 146:147.

Normakiah and Laela HN. 2010. Pengaruh Pemberian Ekstrak Etanol Akar Pasak Bumi (Eurycoma langifolia Jack.) Terhadap Ekspresi Protein p53 pada kanker Payudara Tikus Betina Sparague Dawley (SD) yang diinduksi 7, 12 Dimetilbenz ( $\alpha$ ) Antrasen (DMBA). Jurnal Farmasi Indonesia. 11: 13-15.

Nurhanan MY, HLP Azimahtol, IA Mohamad and MA Shukri. 2005. Cytotoxic Effects of the Root Extracts of Eurycoma langifolia Jack. Phytoterres. 19: 994-996.

Panjaitan RGP. 2008. Pengujian Aktivitas Hepatoprotektor Akar Pasak Bumi (Eurycoma Longifolia Jack). Tesis. Sekolah pascasarjana Institut Pertanian Bogor. 110 hal.

Parikrama, and RR Esyanti. 2014. Effect of UV Elicitation on Callus Growth, Alkaloid and Terpenoid Contents in Eurycoma longifolia Jack. International Journal of Advances in Chemical Engineering \& Biological Sciences.1(1): 12-15

Rahayu B, Solichatun and E Garwulan. 2003. Pengaruh Asam 2,4-Diklorofenoksiasetat (2,4-D) terhadap Pembentukan dan Pertumbuhan Kalus serta Kandungan Flavonoid Kultur Kalus Acalypha indica L. Biofarmasi. 1:1-6.

Rosmaina and Zulfahmi, 2013. Genetic Diversity of Eurycoma longifolia Jack Based on Random Amplified Polymorphic DNA Marker. Jurnal Manajemen Hutan Tropika. XIX (2): 138144.

Sanmugam F, S Aman and T Shajahan. 2014. The beneficial attribute and Seed histology of recalcitrant (Eurycoma longifolia) plants during. International Journal of Histology and Cytology Vol. 1 (1): 005-009

Setyowati FM. 2010. Etnofarmakologi dan Pemakaian Tanaman Obat Suku Dayak Tunjung di Kalimantan Timur. 20: 104112.

Sindelar RD, LA Walker, S Vangapandu and Guo. 2005. Biologically active quassinoids and their chemistry: potential leads for drug design. Current Medicinal Chemistry. 12: 173-190.

Siregar LAM, LK Chan and PL Boey. 2006. Pertumbuhan dan Akumulasi Alkaloid dalam Kalus dan Suspensi Sel Eurycoma longifolia Jack. Jurnal IImiah Pertanian Kultural. 41: 19-27.

Siregar LAM, LK Chan and PL Boey. 2010. Pengaruh Kasein Hidrolisat dan Intensitas Cahaya Terhadap Produksi Biomassa dan Alkaloid Canthinonedi dalam Kultur Subsensisel Pasak Bumi 
(Eurycoma longifolia Jack). Makara Sains. 14: 15-21.

Siregar LAM. 2008. Pengaruh Sitokinin Eksogen dan Sukrosa terhadap Produksi Biomassa dan Alkaloid Canthinone di dalam Kultur Suspensi Sel PasakBumi (Eurycoma longifolia Jack.). Jurnal Natur Indonesia. 12: 143-151.

Sitorus EN, DH Endah and S Nintya. 2011. Induksi Kalus Binahong (Basella rubra L.) Secara In Vitro Pada Media Murashige \& Skoog Dengan Konsentrasi Sukrosa Yang Berbeda. Bioma. 13: 1410-8801.

Solfan B, Zulfahmi, Rosmaina. 2010. Konservasi Eks-situ Pasak Bumi (Eurycoma longifolia Jack). Laporan Penelitian UIN SUSKA. Pekanbaru

Susilowati A. 2008. Teknik Perbanyakan dan Kekerabatan Genetic Pasak Bumi (Eurycoma longifolia Jack). Tesis. Sekolah Pascasarjana Institut Pertanian Bogor, Bogor. 64 hal.

Sutini, Tatik, Wahyu, Sutiman and Sumitro. 2008. Meningkatkan Produksi Flavan-3ol Melalui Kalus Camellia sinensis L. dengan Elisator Cu2+. Jurnal penelitian hayati. 14: 39-49.

Tee TT and HLP Azimahtol. 2005. Induction of Apoptosis by Eurycoma longifolia Jack Extracts. Anticancer Research 25: 22052214

Utami, P. 2008. Buku Pintar Tanaman Obat. Agromedia. Jakarta.

Vijendren K, Syahida A and Maziah M. 2010. Callus Induction of Selected Malaysian Medicinal Plants. Proceedings of the 11th Symposium for the Malaysian Society of Applied Biology. "Biological Balance Towards Life Sustainability" 428-431

Zawawi DD, H Ja'afar, R Zainuddin, R Kari, and M M Noor. 2014. Thidiazuron Induce High Frequency Direct Somatic Embryogenesis Growth from Cotyledon Culture of Eurycoma Longifolia. International Conference on Agriculture, Biology and Environmental Sciences (ICABES'14) Dec. 8-9, 2014 Bali (Indonesia). P.30-34

Zulkarnain dan Lizawati. 2011. Proliferasi Kalus dari Eksplan Hipokotil dan Kotiledon Tanaman Jarak Pagar (Jatropha curcas L.) pada Pemberian 2,4-D. Jurnal Natur Indonesia, 14 (1): 19-25. 


\section{$\mathbf{J}$

PERUBAHAN SIFAT KIMIA TANDAN KOSONG KELAPA SAWIT YANG DIFERMENTASI DENGAN EM4 PADA DOSIS DAN LAMA PEMERAMAN YANG BERBEDA

Changes Of Chemical Properties Compost Oil Palm Empty Fruit Bunch Fermented With Em4 Dosage And Long Different Ripening

Abdul Rahman Toiby, Elfi Rahmadani, dan Oksana

PEMANFAATAN BEBERAPA JENIS DAN DOSIS LIMBAH KELAPA SAWIT (Elaeis guinensis Jacq) TERHADAP PERUBAHAN PH, N, P, K TANAH PODSOLIK MERAH KUNING (PMK)

Fitri Ramadhani, Ervina Aryanti, dan Robbana Saragih

UPAYA PENINGKATAN HASIL MENTIMUN SECARA ORGANIK DENGAN SISTEM TASALAMPOT

Increasing the Yields of Cucumber by Tasalampot Organic Farming System

Indah Permanasari dan Aulia Rani Annisava

PERTUMBUHAN BIBIT KELAPA SAWIT (Elaeis guineensis Jacq.) DI PEMBIBITAN UTAMA PADA MEDIUM SUB SOIL ULTISOL YANG DIBERI ASAM HUMAT DAN KOMPOS TANDAN KOSONG KELAPA SAWIT

The Growth of Palm Seedlings (Elaeis guineensis Jacq.) at the Experiment Farm By Using Medium Of Subsoil Ultisol That Was Treated With Humic Acid and Fruitless Palm Bunch Compost

Janrico Valentino Sembiring, Nelvia, dan Arnis En Yulia

INDUKSI KALUS PASAK BUMI (Eurycoma longifolia Jack) MELALUI EKSPLAN DAUN DAN PETIOL

Callus Induction of Eurycoma longifolia Jack by Leaf and Petiole Explant

Rosmaina, Zulfahmi, Probo Sutejo, Ulfiatun, dan Maisupratina

KEPADATAN DAN POLA PENYEBARAN PASAK BUMI (Eurycoma longifolia Jack) DI ZONA ALAMAN KUYANG, HUTAN LARANGAN ADAT KENEGARIAN RUMBIO

Density and Distribution Pattern of Eurycoma longifolia Jack) In The Alaman Kuyang Zone of The Forest Reserve of Kenegarian Rumbio

Zulfahmi, Nelawati, Rosmaina 